\title{
PENGEMBANGAN MOBILE LEARNING BERBASIS ANDROID MENGGUNAKAN ARTICULATE STORYLINE 3 DI SEKOLAH DASAR
}

\author{
Zila Razilu ${ }^{1)}$ \\ ${ }^{1}$ Universitas Muhammadiyah Kendari, Kota Kendari, Indonesia \\ Email: zila.razilu@umkendari.ac.id
}

\begin{abstract}
Abstrak
Observasi awal yang dilakukan di SD Negeri 10 Mandonga ditemukan informasi bahwa guru yang mengajar mata pelajaran komputer belum menggunakan mobile learning. Media yang digunakan adalah media berbasis komputer berupa power point yang digunakan dalam pembelajaran. Tujuan dari penelitian ini untuk mengembangkan media pembelajaran dengan menggunakan aplikasi articulate storiline 3 pada mata pelajaran komputer di sekolah dasar kelas V. Penelitian ini menggunakan metode penelitian pengembangan (research and development). Sampel dalam penelitian ini adalah seluruh siswa kelas V SD Negeri 10 Mandonga yaitu 20 siswa. Teknik pengambilan data yang digunakan dalam penelitian ini adalah angket, dokumentasi, dan observasi. hasil uji validasi oleh ahli media pembelajaran diperoleh persentase sebesar $81,5 \%$ yang berarti terkategori layak. Penilaian dari ahli materi diperoleh persentase sebesar 86,36\% yang berarti masuk dalam kategori sangat layak digunakan. Penilaian dari 20 orang siswa kelas V SD Negeri 10 Mandonga diperoleh persentase rata-rata sebesar 94,54\% yang berarti masuk dalam kategori sangat layak digunakan. Hasil uji ini menunjukkan bahwa pengembangan mobile learning menggunakan articulate storyline 3 pada mata pelajaran komputer di SD Negeri 10 Mandonga terkategori sangat layak untuk digunakan dalam pembelajaran.
\end{abstract}

Kata kunci: articulate storyline 3; mobile learning; pengembangan.

\section{ANDROID-BASED MOBILE LEARNING DEVELOPMENT USING ARTICULATE STORYLINE 3 IN ELEMENTARY SCHOOL}

\begin{abstract}
Initial observations made at SD Negeri 10 Mandonga found information that teachers who teach computer subjects have not used mobile learning. Media used is computer-based media in the form of power points used in learning. The purpose of this research is to develop learning media by using articulate storiline 3 application in computer subjects in elementary school grade $V$. This research uses research and development method. The samples in this study were all grade V students of SD Negeri 10 Mandonga, namely 20 students. Data retrieval techniques used in this research are questionnaires, documentation, and observation. validation test results by learning media experts obtained a percentage of $81.5 \%$ which means categorized as feasible. The assessment from the material expert obtained a percentage of $86.36 \%$ which means it fall into the category of very worthy of use. The assessment of 20 students in grade $V$ of SD Negeri 10 Mandonga obtained an average percentage of $94.54 \%$ which means that it is very feasible to use. The results of this test showed that the development of mobile learning using articulate storyline 3 in computer subjects at SD Negeri 10 Mandonga is categorized as very feasible for use in learning.
\end{abstract}

Keywords: articulate storyline 3; mobile learning; development.

\begin{tabular}{|cccc|}
\hline Submitted: & Reviewed: & Accepted: & Published: \\
15 Maret 2021 & 16 Maret 2021 & 16 Maret 2021 & 31 Maret 2021 \\
\hline
\end{tabular}

Penerbit: Pendidikan Teknologi Informasi FKIP Universitas Muhammadiyah Kendari 


\section{PENDAHULUAN}

Perkembangan Teknologi Informasi dan Komunikasi (TIK) atau Information Communication and Technology (ICT) di zaman modern ini sangat berpengaruh dalam kehidupan sehari-hari bagi semua kalangan, baik pelajar maupun mahasiswa. Salah satu bukti nyatanya ialah penggunaan smartphone. Tingkat perkembangan perangkat smartphone saat ini sudah semakin tinggi dan relatif murah. Hal tersebut yang menjadi faktor pendukung penyebab pengguna smartphone meningkat. Menurut Asosiasi Penyelenggara Jasa Internet Indonesia (APJII), pengguna smartphone di Indonesia pada tahun 2016 sudah mencapai 67,8\%. Lembaga riset digital marketinge-marketer dalam Kominfo RI, pada tahun 2018 Indonesia akan menjadi negara dengan jumlah pengguna aktif smartphone lebih dari 100 juta orang. Jumlah sebesar itu telah menjadikan Indonesia negara dengan pengguna aktif smartphone terbesar keempat di dunia setelah Cina, India, dan Amerika. Data menunjukkan bahwa $18,4 \%$ penggunanya adalah anak-anak dan remaja yang statusnya masih pelajar. Faktanya, mayoritas pelajar menggunakan smartphone hanya untuk bermain games dan media sosial. Hal ini akan mengganggu kegiatan belajar mereka, karena lebih fokus melihat smartphone, bahkan sampai kecanduan. Selain untuk menanggulangi hal tersebut, smartphone dengan segala kemudahannya menjadi sangat tepat untuk dapat digunakan sebagai salah satu bentuk media pembelajaran (Astuti, Sumarni, \& Saraswati, 2017).

Karakteristik penggunaan smartphone sebagai media pembelajaran atau disebut mobile learning ialah memiliki tingkat fleksibilitas yang sangat tinggi (Wirawan, 2011). Sebagai pelengkap pembelajaran yang ada, mobile learning memungkinkan penggunanya dapat mengakses materi, arahan, dan informasi yang berkaitan dengan pembelajaran kapanpun dan dimanapun. Mobile learning merupakan salah satu alternatif pengembangan media pembelajaran yang dapat dimanfaatkan sebagai suplemen pembelajaran sehingga mampu melatih siswa untuk belajar mandiri (Arief, 2014). Permasalahan ini semakin menambah kinerja guru dalam hal menyiapkan media pembelajaran. Kompleksnya tugas guru menuntut setiap guru untuk memiliki perilaku organizational citizenship behavior dalam bentuk pengembangan diri (Salim, et., al.). Guru sebagai fasilitator dalam kegiatan pembelajaran harus memiliki kompetensi dalam menggunakan TIK/ICT. Kompetensi guru, meliputi kompetensi pedagogik, kompetensi kepribadian, kompetensi sosial, dan kompetensi profesional yang diperoleh melalui pendidikan profesi. Pada kompetensi pedagogik, terdapat poin pemanfaatan teknologi pembelajaran sehingga guru harus mampu melaksanakan pembelajaran berbasis teknologi, baik web-based education, e-learning, juga mobile learning untuk menunjang proses pembelajaran dalam peningkatan dan percepatan mutu pendidikan (Daryanto,2013).

Observasi awal yang dilakukan di SD Negeri 10 Mandonga ditemukan informasi bahwa guru yang mengajar mata pelajaran komputer belum menggunakan mobile learning. Media yang digunakan adalah media berbasis komputer berupa power point yang digunakan dalam pembelajaran. Penggunaan media ini belum mampu memfasilitasi kebutuhan belajar saat ini yang mengharuskan pembelajaran dilakukan kapan saja dan dimana saja. Berdasarkan hal tersebut, maka perlu adanya media baru menggunakan smartphone. Oleh karena itu, pengembangan mobile learning menjadi sangat urgen untuk dilaksanakan.

\section{METODE}

Penelitian ini menggunakan metode penelitian pengembangan (Research and Development). Metode Penelitian pada dasarnya merupakan cara ilmiah untuk mendapatkan data dengan tujuan dan kegunaan tertentu (Sugiyono, 2011). Berdasarkan hal tersebut terdapat empat kata kunci yang perlu diperhatikan yaitu cara ilmiah, data, tujuan, dan 


\section{DECDDE: Jurnal Pendidikan Teknologi Informasi, I (1) (2020): 17-21}

\section{Pengembangan Mabile Learning Berbasis Andraid Menggunakan Articulate Staryline 3 di Sekulah Dasar}

kegunaan. Sampel dalam penelitian ini adalah seluruh siswa kelas V SD Negeri 10 Mandonga yaitu 20 siswa. Teknik pengambilan data yang digunakan dalam penelitian ini adalah angket, dokumentasi, dan observasi.

Analisis data pada penelitian ini adalah menggunakan teknik analisis deskriptif kualitatif yang memaparkan hasil pengembangan produk berupa media pembelajaran berbasis android yang diimplementasikan pada mata pelajaran komputer . Data yang diperoleh melalui instrumen penilaian pada saat uji coba dianalisis dengan menggunakan statistik deskriptif kualitatif.

\section{HASIL DAN PEMBAHASAN}

Hasil dari penelitian ini adalah terciptanya media pembelajaran berupa mobile learning menggunakan aplikasi Articulate Storiline 3 pada mata pelajaran komputer. Aplikasi yang dibuat dapat digunakan pada smartphone secara offline, dimana dalam aplikasi ini didominasi oleh teks dan gambar. Pada tampilan awal aplikasi yang menampilkan sambutan atau ucapan selamat datang kepada pengguna atau user. Aplikasi ini memuat menu utama, menu materi yang berisi mata pelajaran komputer, menu kuis sebagai evaluasi dari mata pelajaran komputer, menu petunjuk yang berisi tentang penggunaan masing-masing menu aplikasi. Adapun tampilan media yang dikembangkan dapat dilihat pada beberapa gambar berikut.
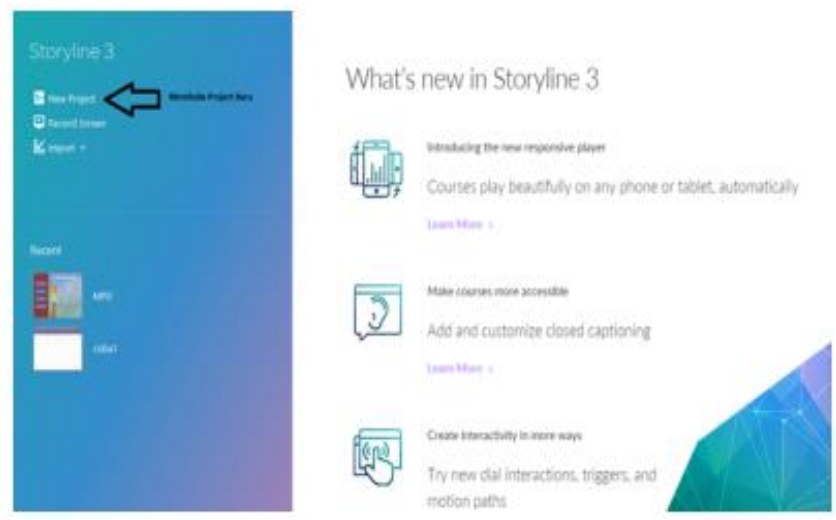

Gambar 1. Tampilan Awal Aplikasi

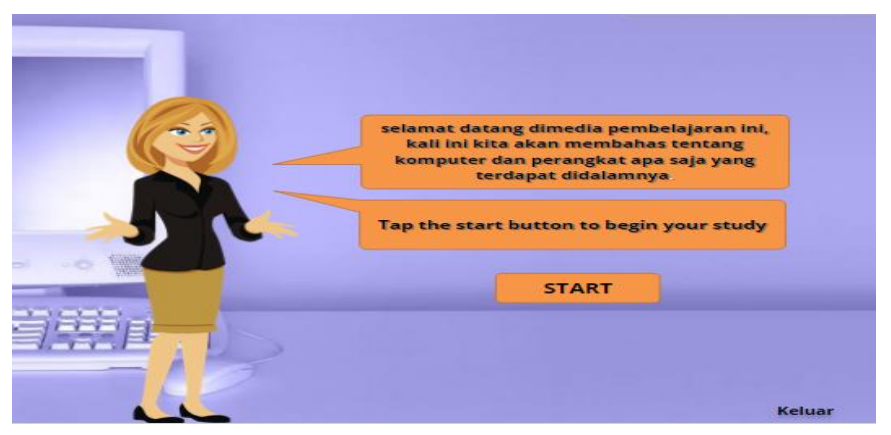

Gambar 2. Tampilan Pembuka 


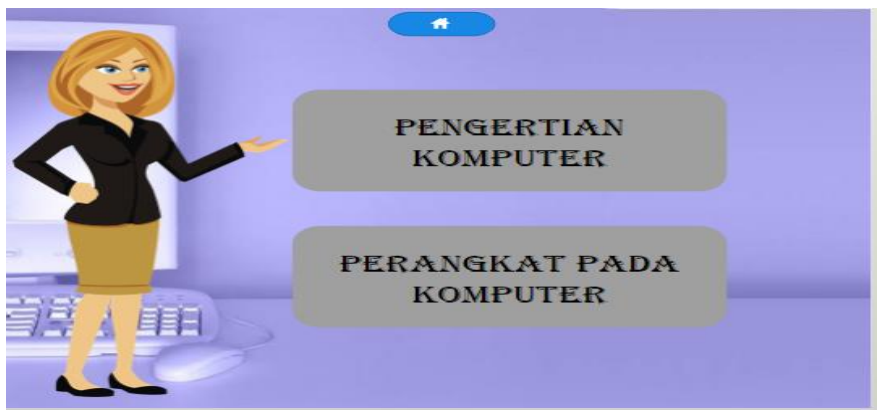

Gambar 3. Tampilan Menu Materi

Tahap pengujian aplikasi komputer dilakukan dengan tahap uji validasi yang melibatkan beberapa responden, diantaranya: 2 orang ahli media, 1 orang ahli materi, dan 20 siswa SD Negeri 10 Mandonga Kota Kendari. Proses pengumpulan data dilakukan dengan mengajukan angket (kuisioner) sebagai instrument pada masing-masing responden. Data dan saran yang diperoleh dari instrument digunakan sebagai bahan perbaikan dan revisi pada aplikasi $\mathrm{r}$.

Data hasil uji validasi ahli media, ahli materi, dan uji lapangan aplikasi belajar komputer berbasis android di SD Negeri 10 Mandonga kelas V disajikan pada gambar 4 berikut:

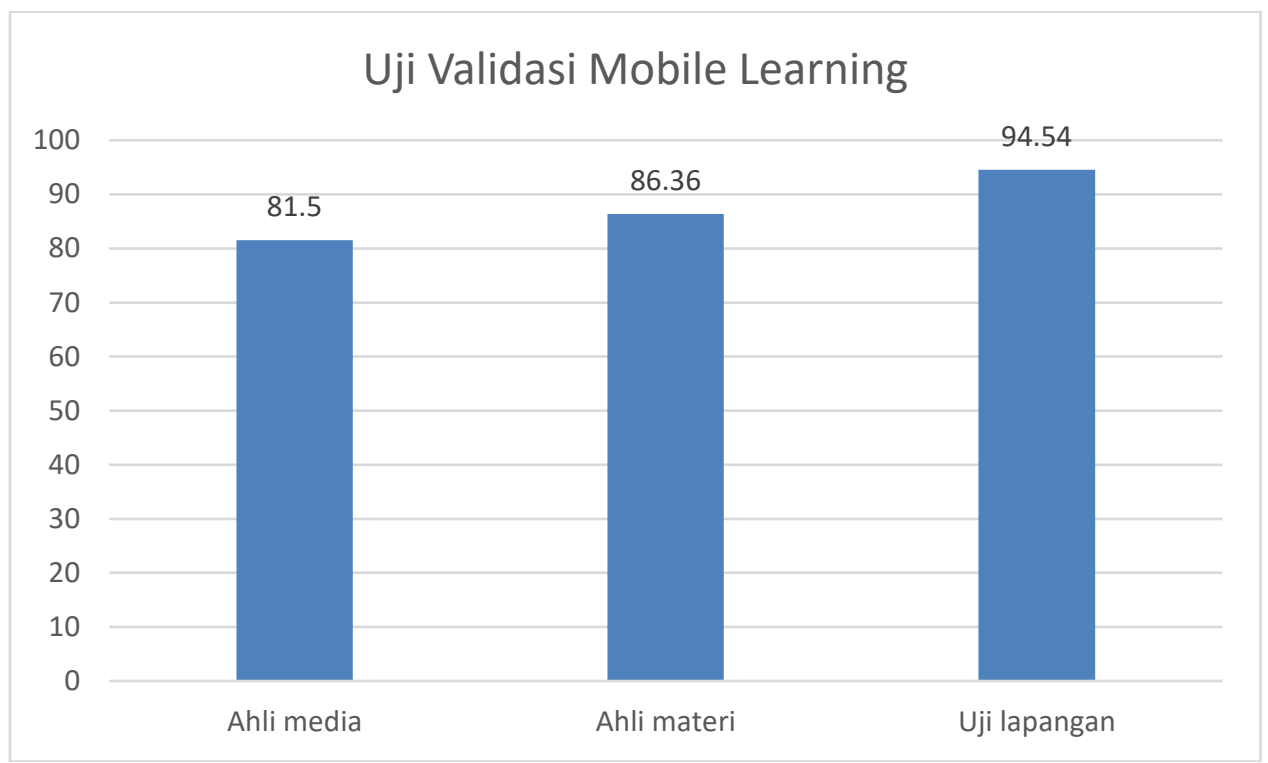

Gambar 4. Hasil Uji Validasi Mobile Learning

Berdasarkan gambar di atas, hasil uji validasi oleh ahli media pembelajaran diperoleh persentase sebesar $81,5 \%$ yang berarti terkategori layak. Penilaian dari ahli materi diperoleh persentase sebesar $86,36 \%$ yang berarti masuk dalam kategori sangat layak digunakan. Penilaian dari 20 orang siswa kelas V SD Negeri 10 Mandonga diperoleh persentase rata-rata sebesar 94,54\% yang berarti masuk dalam kategori sangat layak digunakan. Hasil uji ini menunjukkan bahwa pengembangan mobile learning menggunakan articulate storyline 3 pada mata pelajaran komputer di SD Negeri 10 Mandonga terkategori sangat layak untuk digunakan dalam pembelajaran.

Hasil penelitian ini sesuai dengan penelitian (Ibrahim \& Ishartiwi, 2017) yang dalam penelitiannya berkesimpulan bahwa produk mobile learning dinyatakan layak sebagai media pembelajaran berdasarkan penilaian ahli media dan ahli materi dengan kategori sangat baik. 
(Hardinata, Murwitaningsih, \& Amirullah, 2018) dalam penelitiannya menyimpulkan media pembelajaran mobile learning berbasis android layak digunakan sebagai sumber belajar.

\section{KESIMPULAN DAN SARAN}

Hasil dari penelitian ini menghasilkan media pembelajaran berbasis android yang dapat digunakan dalam proses pembelajaran pada mata pelajaran komputer siswa kelas V SD Negeri 10 Mandonga. Hasil uji validasi oleh ahli media pembelajaran diperoleh persentase sebesar $81,5 \%$ yang berarti terkategori layak. Penilaian dari ahli materi diperoleh persentase sebesar $86,36 \%$ yang berarti masuk dalam kategori sangat layak digunakan. Penilaian dari 20 orang siswa kelas V SD Negeri 10 Mandonga diperoleh persentase rata-rata sebesar 94,54\% yang berarti masuk dalam kategori sangat layak digunakan.

Demi pengembangan lebih lanjut, maka peneliti memberikan saran yaitu bagi peneliti berikutnya yang akan melakukan pengembangan tentang pengembangan mobile learning berbasis android menggunakan articulate storiline 3 pada mata pelajaran komputer kelas $\mathrm{V}$ disarankan untuk menambahkan menu video tutorial yang langsung terhubung ke youtube agar siswa atau pengguna dapat dengan mudah belajar tentang komputer.

\section{DAFTAR PUSTAKA}

Arief, S. (2014). Media Pendidikan: Pengertian, Pengembangan, dan Pemanfaatannya. Jakarta: Rajawali Pers.

Astuti, I. A. D., Sumarni, R. A., \& Saraswati D. H. (2017). Pengembangan Media Pembelajaran Fisika Mobile Learning Berbasis Android. Jurnal Penelitian dan PengembanganPendidikan Fisika, 3(1), 57-62.

Daryanto, D. (2013). Media Pembelajaran Peranannya Sangat Penting Dalam Mencapai Tujuan Pembelajaran. Yogyakarta: Gava Media.

Hardinata, R., Murwitaningsih, S., \& Amirullah, G. (2018). Pengembangan Mobile Learning Sistem Koordinasi Berbasis Android. Bioeduscience, 2(1), 53-58. https://doi.org/10.29405/j.bes/2153-581334

Ibrahim, N., \& Ishartiwi. (2017). Pengembangan Media Pembelajaran Mobile Learning Berbasis Android Mata Pelajaran IPA untuk Siswa SMP. Jurnal Refleksi Edukatika, 8(1), 80-88. https://doi.org/10.24176/re.v8i1.1792

Salim., Prajono, R., Nurhayati., Abdin., \& Saputra, H. N. (2020). Teacher Behavior Profile in Organization Citizenship Behavior. PEDAGOGIA: Jurnal Pendidikan, 9(2), 225-241. https://doi.org/10.21070/pedagogia.v9i2.754

Sugiyono, P. D. (2013). Metode Penelitian Pendidikan. Bandung: Alfabeta.

Wirawan, I. M. A. dan Ratnaya I. G. (2011). Pengembangan Desain Pembelajaran Mobile Learning Management System pada Materi Pengenalan Komponen Jaringan. Jurnal Penelitian dan Pengembangan Pendidikan, 5(3), 314-324.

\section{How to cite:}

Razilu, Z. (20Z1). Pengembangan Mobile Learning Berbasis Andraid Menggunakan Articulate Storyline 3 di Sekulah Dasar. DECDDE: Jurnal Pendidikan Teknolagi Infarmasi, ((I), 17-21. DDI: http://dx.dai.org/l0.51454/decode.vlil.3 